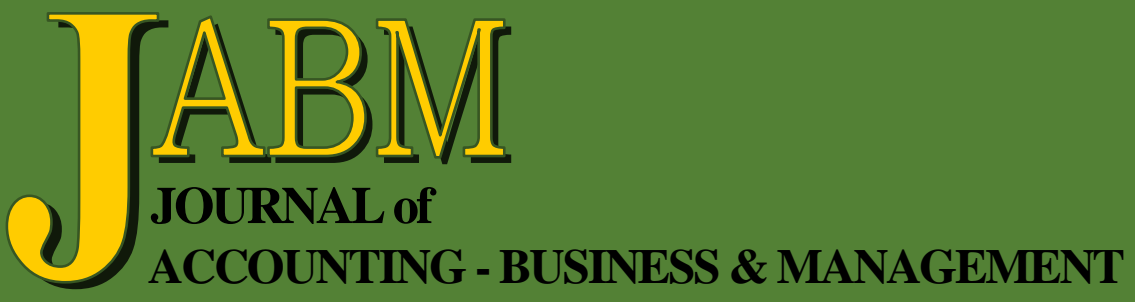

The Relationship between the Ownership Structure, Capital Structure and Performance

Ali Al-Thuneibat

The Effect of Self Efficacy and Information Quality on Behavioral Intention with Perceived Usefulness as Intervening Variable

Muslichah

Empirical Analysis of Factors Influencing Use of Internet on Ships

A. S. Saravanan, Jayalakshmy Ramachandran, A. Seetharaman, Karripur Nandakumar, and Capt. Kailash C. Joshi

Pawnshops Regulatory Environment: A Readability Analysis

Geralyn Miller, Steven A. Hanke, and Hui Di

Auditor Litigation and the Penalties on U.S. Client Firms after the Private Securities Litigation Reform Act

Nana Y. Amoah, Anthony Anderson, Isaac Bonaparte and Kyle Meyer 
Journal of Accounting - Business \& Management vol. 25 no. 1 (2018) 62-72

\title{
Auditor Litigation and the Penalties on U.S. Client Firms after the Private Securities Litigation Reform Act
}

\author{
Nana Y. Amoah* \\ Anthony Anderson ${ }^{\dagger}$ \\ Isaac Bonaparte‡ \\ Kyle Meyer\$
}

\begin{abstract}
This study examines the relation between auditor litigation and the market and legal penalties imposed on sued audit clients after the private securities litigation reform act (PSLRA). A sample of accounting-related lawsuits is used in the regressions of three-day cumulative abnormal returns, settlement amount, and probability of settlement on auditor litigation and other variables. The results indicate a negative relation between auditor litigation and the 3-day cumulative abnormal returns around the announcement of litigation against the client firm. Another result from the study is a positive relation between auditor litigation and the legal penalty on the client firm. Specifically, the results indicate higher likelihood of settlement and larger settlement sizes for securities lawsuits in which the auditor is also sued. Our study contributes to the debate on the merit of litigation against auditors after the PSLRA. The findings imply that lawsuits against auditors appear to be a signal of audit failure and higher financial reporting risk. As audit failures erode investor confidence in the capital markets, the present study provides valuable evidence on the market and legal system's perception of the merit of auditor litigation. The findings should be of interest to regulators and market participants given the increase in securities lawsuits against audit firms and the substantial reputational consequences of such lawsuits on audit firms and client firms.
\end{abstract}

Keywords: financial reporting risk, audit, litigation, penalty, investor reaction, audit failure.

\section{INTRODUCTION}

We examine the relation between auditor litigation and the market and legal penalties imposed on audit clients that are sued for financial misreporting. Extant literature documents that managers engage in opportunistic behavior in the absence of effective monitoring (Collins et al., 2009; Hossain et al., 2011; and Jia, 2014) ${ }^{1}$ and such

\footnotetext{
* Associate Professor, Crummer Graduate School of Business. Rollins College. 1000 Holt Avenue, Winter Park, FL 32789. Phone: 407-646-2593. Email: namoah@Rollins.edu.

† Howard University, School of Business. 2400 Sixth Street, NW, Washington DC, 20059. Phone: 202-806-1587. E-mail: anthony.anderson@howard.edu.

¥ Towson University, College of Business and Economics. 8000 York Road, Towson, MD 21252. Phone: 443-462-7544. E-mail: ibonaparte@towson.edu.

$\$$ Crummer Graduate School of Business, Rollins College. 1000 Holt Avenue, Winter Park, FL 32789. Phone: 407-691- 1377. Email: ksmeyer@Rollins.edu.

1 Fraudulent financial reporting is exacerbated when the board of directors is unable to provide effective oversight over the management of the firm (O'Conner et al., 1992). Failure to provide effective oversight could increase agency costs as managers would have the opportunity to engage in opportunistic behavior (Watts \& Zimmerman, 1983).
} 
opportunistic behavior is associated with misstatements of financial statements. The misleading financial statements could trigger securities lawsuits, which in turn may result in legal and market penalties.

In the aftermath of the disclosure of accounting misstatements, shareholders in some instances, have alleged that the auditors failed to exercise duty of care towards investors in the conduct of their duty which resulted in negative ramifications on investor wealth. Shareholders in such instances have filed securities class actions against client firms and have joined auditors to the lawsuits (Chaney \& Philipich, 2002; Dee et al., 2011).

Whereas in many instances there is consensus on the complicity of sued client firms, the audit firm's culpability in many securities lawsuits appears to be controversial. Litigation against auditors continues to generate intense debate as some argue that such lawsuits typically do not have merit and represent attempts by shareholders to recover losses from auditors because of their deep pockets. However, others argue that in the post private securities litigation reform act (PSLRA) period, securities lawsuits against auditors have merit and are indicative of audit failure and higher financial reporting risk.

In 1995, congress enacted the PSLRA to curtail frivolous securities lawsuits against auditors and client firms. Under the PSLRA, plaintiffs in securities lawsuits are required to provide evidence that supports an inference of intention to commit fraud. The PSLRA also allows judges to sanction plaintiff attorneys if lawsuits are frivolous. While Palmrose (1988) suggests that lawsuits are expensive and that auditors are named as co-defendants when plaintiffs believe that the external auditor has been negligent, audit firms (especially the Big 6) contend that lawsuits brought against them are frivolous and are motivated by their "deep pockets." Coffee (2006) notes that the PSLRA insulated auditors from liability. Not surprisingly, therefore, Lee and Mande (2003) report that audit quality declined after the enactment of the PSLRA. Extant literature documents that the PSLRA, notwithstanding, lawsuits against auditors continue to result in substantial settlements (Talley, 2006; Donelson \& Prentice, 2012; and Donelson, 2013).

Using accounting-related securities lawsuits from the Stanford Securities Class Action Clearinghouse database over the 10-year period after the PSLRA (1996 to 2005), we investigate the relation between auditor litigation and investor reaction to securities lawsuit against the audit client. We also examine the relation between auditor litigation and the outcome of securities lawsuit against the audit client. We find a negative relation between auditor litigation and the 3-day cumulative abnormal returns around announcement of litigation against the client firm. Another result that emerges from our study is a positive relation between auditor litigation and the probability that the client firm will settle the securities lawsuit. We also document a positive relation between auditor litigation and the size of the client firm's lawsuit settlement.

Our study contributes to the debate on the merit of litigation against auditors after the PSLRA. Prior studies have focused on the effect of auditor litigation on the market penalties imposed on client firms that are not sued while our study examines the effect of auditor litigation and audit firm reputation on the market and legal penalties of sued client firms. The findings imply that lawsuits against auditors appear to be a signal of audit failure and higher financial reporting risk. As audit failures erode investor confidence in the capital markets, the present study provides valuable evidence on the market and legal system's perception of the merit of auditor litigation. 
The rest of the study proceeds as follows: section 2 provides the literature review and hypothesis development. Section 3 presents the methodology and section 4 reports the empirical results of the study. The conclusion follows in Section 5.

\section{LITERATURE REVIEW AND HYPOTHESIS DEVELOPMENT}

Auditors have a fiduciary duty towards a firm's shareholders and are expected to conduct an independent examination of the financial statements of the firm. Given that auditors play an important role in enhancing the level of assurance with respect to financial statements, audit failures have serious ramifications on investor capital and the survival of companies (Chaney \& Philipich, 2002). A securities class action lawsuit following an audit failure facilitates the recovery of investor losses, penalizes the perpetrators of the unacceptable acts, and triggers changes in a firm's corporate governance mechanisms (Fich \& Shivdasani, 2007; Cheng et al, 2010; McTier \& Wald, 2011; and Crutchley et al., 2015). Fuerman (2006) reports that auditors are more likely to be joined to a lawsuit when financial statements are restated, firms become bankrupt after an audit that fails to issue any red flags, or allegations of fraud are brought against the client firm.

Consistent with the important role of auditors in investor decision-making, investors adjust the value of client firms in response to audit failures and the elevation of financial reporting risk (Chaney \& Philipich, 2002). Extant literature reports an association between the market value of client firms and auditor reputation and audit quality (Chaney \& Philipich, 2002; Franz et al., 1998; and Dee et al., 2011).

For example, Sharad et al. (2010) examine the valuation effects of auditor change announcements by former Andersen clients. They find that client firms switching from Andersen experienced positive abnormal returns during the three-day window surrounding announcement of the switch. Positive market reactions to the switch from Anderson could be due to the heightened reputational risk associated with Anderson and reduction in the uncertainty related to the cost of hiring a new external auditor.

In a related study, Krishnamurthy et al. (2006) examine the impact of the decline in Andersen's reputation on the market's perception of Andersen's audit quality. Specifically, Krishnamurthy et al. (2006) examine abnormal market returns for clients of Arthur Andersen around the time of the indictment announcement as well as investor reaction to the announcement of Andersen's dismissal by client firms. They report that Andersen clients suffered significantly negative market reactions around the indictment announcement and the negative reaction was more pronounced when the market perceived that the auditor's independence was compromised. Relative to firms that quickly switched to non-Big 4 or that did not announce replacement auditors after dismissing Andersen, firms that quickly switched to Big 4 auditors experience higher abnormal returns.

Dee et al. (2011) also examine the market reaction to news of public company accounting oversight board's (PCAOB) sanctions against Deloitte and Touche, LLP for its audit of Ligand Pharmaceuticals Incorporated. Using a sample of 707 Deloitte and 2,363 non-Deloitte clients, Dee et al. (2011) document that relative to non-Deloitte clients, Deloitte clients experienced significantly negative market reaction. They document that non-Deloitte clients experienced positive and significant mean cumulative abnormal returns on the event date (day 0 ).

Given that securities lawsuits against auditors allege audit failure and the auditor's culpability in the alleged fraud, it is expected that announcement of a securities lawsuit against an auditor will trigger a negative reaction to the stock price of client 
firms. In line with this expectation, Franz et al. (1998) document that non-sued clients of an auditor experience significantly negative abnormal returns following announcement of litigation against the auditor. Franz et al. (1998) suggest that the negative market reaction to the market value of client firms that are not sued could be attributed to the expectation that the financial statements of the non-sued client firms may also be materially misstated and misleading.

To make the audit report more informative to users, the PCAOB adopted a new auditing standard on June 1, 2017. The new auditing standard requires that auditors disclose critical audit matters (CAMs) in the audit report to augment its relevance and usefulness to investors and other stakeholders. Brasel et al. (2016) and Kachelmeier et al. (2014) suggest that the disclosure of critical audit matters in the audit report could potentially reduce auditor liability.

We note that the PSLRA which was enacted to curtail frivolous securities lawsuits reduced the legal liability of auditors as securities lawsuit plaintiffs are required to supply facts that demonstrate fraud intent to avoid dismissal of their lawsuit. The securities lawsuit filing is also required to prove that the misstatement caused the alleged losses incurred by shareholders. Under the PSLRA, the costly discovery process which coerced auditors and client firms to settle lawsuits is deferred to the period after the ruling on the motion to dismiss the lawsuit. Moreover, the proportional liability rules under the PSLRA implies that an auditor is typically liable for a proportion of the total damages rather than up to $100 \%$ of the damages under the joint and several liability rule (in the pre-PSLRA period) which pressured auditors to settle lawsuits even if the lawsuit was frivolous. ${ }^{2}$ The PSLRA also allows judges to impose sanctions on plaintiff attorneys that file frivolous lawsuits (against auditors) motivated by the perceived "deep pockets" of auditors. Thus, we argue that auditor litigation will be considered as a more credible signal of financial reporting risk and audit failure with respect to the client firm's financial statements, and the market and legal systems will impose greater penalties on audit clients.

Auditors appear to have more liability relief in the post-PSLRA legal environment, making it costlier to file frivolous securities lawsuits against them. We therefore expect that auditor litigation will be considered by the market and legal systems as additional information about audit failure, an indication of more adverse financial statement misstatements and shareholder losses, which in turn should result in an increase in the legal and market penalties imposed on the sued audit client. Accordingly, the following are our hypotheses:

$\mathbf{H}_{1}$ : investor reaction to announcement of securities lawsuit against a client firm will be more negative when the auditor is also sued.

$\mathbf{H}_{2}$ : settlement sizes for securities lawsuits against client firms will be greater when the auditor is also sued.

$\mathbf{H}_{3}$ : securities lawsuits against client firms are more likely to be settled when the auditor is also sued.

\footnotetext{
2 Under the PSLRA, joint and several liability is not allowed except in cases of intentional
} violation of securities law. 


\section{METHODOLOGY}

\subsection{Sample and Data Collection}

We obtain data on stock returns from the CRSP database and data on accounting-related lawsuit filings from the Stanford Securities Class Action Clearinghouse database for the period 1996 to 2005. We extract firm financial data from the Compustat database. In arriving at our final sample of 301 litigation firms, we delete from the sample, firms that have missing CRSP, Compustat, and Litigation data. Also excluded from the sample are lawsuit filings confounded by concurrent events such as earnings and restatement announcements. Consistent with Karpoff et al. (2008), we verify and supplement our lawsuit data using the Lexis Nexis database.

\subsection{Hypotheses Testing Model}

To examine the relation between auditor litigation and market and legal penalties on the audit client, the following is the general form of our model:

\section{Penalty $=\alpha+\beta_{1}$ Lev $+\beta_{2}$ LnAssets $+\beta_{3} B M+\beta_{4}$ Irregularity $+\beta_{5}$ Audlitig $+\varepsilon$}

Our Penalty variables are: (1) 3 -day CAR - the market penalty levied on the audit client firm, which is defined as the cumulative abnormal return over the 3 -day period beginning on the day before the litigation announcement and ending a day after the litigation announcement; (2) LnSettleAmt - the legal penalty, which is defined as the Log of the dollar settlement amount; and (3) Settlement - probability of settlement, which is a binary variable equal to 1 , if the lawsuit is settled by the audit client, zero otherwise.

Our test variable in the regression model is Audlitig (Auditor litigation). Audlitig is a binary variable equal to 1 , if the auditor is named as a defendant in the securities lawsuit, zero, otherwise. We expect that the coefficient of Audlitig in the market penalty (3-day CAR) regression will be negative as investors will react more negatively to a litigation announcement when the auditor is also sued. Conversely, the coefficient of Audlitig in the LnSettleAmt and Settlement regressions should be positive as we expect that auditor litigation should be associated with a higher probability of settlement and a larger settlement size.

Our other independent variables are Lev, LnAssets, BM, and Irregularity. We include Lev (leverage) computed as the ratio of total liabilities to total assets in the regression model as highly leveraged firms are more likely to engage in opportunistic behavior to avert tighter debt covenants, which in turn could trigger securities lawsuits and result in market and legal penalties (Defond \& Jiambalvo, 1994; Lys \& Watts, 1994).

We include LnAssets (log of total assets) in the regression model to control for the size of the client firm. We expect that larger firms will be levied larger legal and market penalties (Lys \& Watts, 1994). We also include BM (ratio of the book value of equity to the market value of equity) in our model as growth firms are less likely to have effective internal controls thereby increasing financial reporting risk (Jensen, 2005). Finally, we include Irregularity (accounting irregularity) in our model to control for the seriousness of the misstatement. Irregularity is a binary variable equal to 1 , if the accounting misstatement is due to an irregularity, zero, otherwise. We expect that securities lawsuits triggered by accounting irregularities will be associated with larger market and legal penalties. 


\section{EMPIRICAL RESULTS}

Table 1 presents the descriptive statistics of the continuous variables and binary variables. Panel A of Table 1 shows that the mean (median) leverage of the firms contained in the sample is 0.5568 (0.5626); the mean (median) of LnAssets is 7.6013 (7.4240); the mean (median) of BM is 0.0453 (0.0009); and, the mean (median) of LnSettleAmt is 7.9567 (0.0000). Panel A also reports the three-day cumulative abnormal returns over the event window $[-1,+1]$ relative to the securities lawsuit filing announcement date (day,0). The abnormal returns are computed similar to Brown and Warner (1985) utilizing a single-factor market model, the CRSP equally-weighted market index, and a 255-day estimation period ending 45 days prior to the lawsuit announcement. The mean (-0.0441) and median (-0.0162) of 3-day CAR are both statistically significant at the 1\% level. We infer from Panel A of Table 1 that the market exhibited a significantly negative market reaction within the three days following the announcement of auditor litigation. This finding is consistent with prior research (Chaney \& Philipich, 2002; Koku; 2006).

\section{Table 1}

\section{Descriptive Statistics}

Table 1 presents the descriptive statistics of the continuous and binary variables. Panel A and Panel B report the descriptive statistics of the continuous and binary variables, respectively. Lev is the ratio of total liabilities to total assets. LnAssets is the log of total assets. BM is the ratio of book to market value of equity. 3-Day CAR is the three-day cumulative abnormal returns around the announcement of litigation against the client firm. $\mathrm{LnSettleAmt} \mathrm{is} \mathrm{the} \mathrm{log} \mathrm{of} \mathrm{the} \mathrm{dollar} \mathrm{settlement} \mathrm{amount.} \mathrm{Irregularity} \mathrm{is} \mathrm{a} \mathrm{binary} \mathrm{variable} \mathrm{equal}$ to 1 , if the accounting misstatement is due to an irregularity, 0 , otherwise. Audlitig is equal to 1 , if the audit firm is sued, 0 , otherwise. Settlement is a binary variable equal to 1 , if the client firm settles the lawsuit, 0 , otherwise.

\begin{tabular}{lccc}
\hline \multicolumn{4}{l}{ Panel A: Continuous Variables $(\mathbf{N}=\mathbf{3 0 1})$} \\
\hline \multicolumn{1}{c}{ Variable } & Mean & Median & Std. dev. \\
\hline Lev (TL/TA) & 0.5568 & 0.5626 & 0.2507 \\
LnAssets & 7.6013 & 7.4240 & 1.9386 \\
BM & 0.0453 & 0.0009 & 0.1363 \\
LnSettleAmt & 7.9567 & 0.0000 & 8.4589 \\
3-Day CAR & -0.0441 & -0.0162 & 0.1554 \\
\hline
\end{tabular}

Panel B: Binary Variables ( $N=301)$

\begin{tabular}{lccc}
\hline & $\begin{array}{c}\text { Number } \\
\text { of Firms }\end{array}$ & Percentage & Sample Size \\
\cline { 4 - 4 } & 81 & $26.91 \%$ & $\mathbf{N}$ \\
\hline Irregularity & 33 & $10.96 \%$ & 301 \\
Audlitig & 163 & $54.15 \%$ & 301 \\
Settlement & 163 & 301 \\
\hline
\end{tabular}

We infer from Panel B of Table 1 that firms that engaged in accounting irregularities represent $26.91 \%$ of the sample. Panel B of Table 1 also shows that $10.96 \%$ of the firms in our sample were involved in lawsuits that named the auditor as co-defendant. Further, Panel B of Table 1 shows that $54.15 \%$ of the firms in our sample settled their securities lawsuits.

Table 2 presents the distribution of the securities lawsuits across the sample period and the industry distribution (based on the first two digits of the SIC code) of the sample firms. We infer from Panel A of Table 2 that the highest number of lawsuits (41) occurred in 2002 representing 13.62\% of the lawsuits in our sample. The second highest number of securities lawsuits (40) were filed against client firms in 1999, 
representing $13.29 \%$ of the sample. Twenty-one securities lawsuits were filed in 2005 , representing $6.98 \%$ of the sample while the lowest number of lawsuits (15) in the sample, representing 4.98\% of the sample, were filed in 1996. Panel A of Table 2 indicates a drop in the number of lawsuits in 1996, which is the year after passage of the PSLRA, and a steady increase thereafter. The increase in lawsuits after 1996 suggests that the PSLRA has not succeeded in curtailing securities lawsuits. Panel A of Table 2 also indicates an increase in securities class action lawsuits in the year SOX was enacted. Consistent with Fuerman (2012), we note that there is a gradual decline in securities lawsuits in the years after the passage of SOX. The decline in securities lawsuits could be associated with the strengthening of corporate governance mechanisms after the enactment of SOX.

We infer from Panel B of Table 2, based on the first two digits of the SIC code, that the industry with the most number of lawsuits $(11.63 \%)$ is Business Services (2digits SIC code= 73). The industry with next highest number of lawsuits $(10.63 \%)$ is the Chemical and Allied Products Industry (2-digit SIC code= 28).

\section{Table 2}

\section{Distribution of the Event Year and Industry Classification for Shareholder} Litigation

Table 2 presents the distribution of the securities lawsuits across the sample period and the industry distribution of the sample firms. Panel A presents the distribution of the lawsuits across the sample period (1996-2005) and Panel B presents the industry distribution of the sample firms.

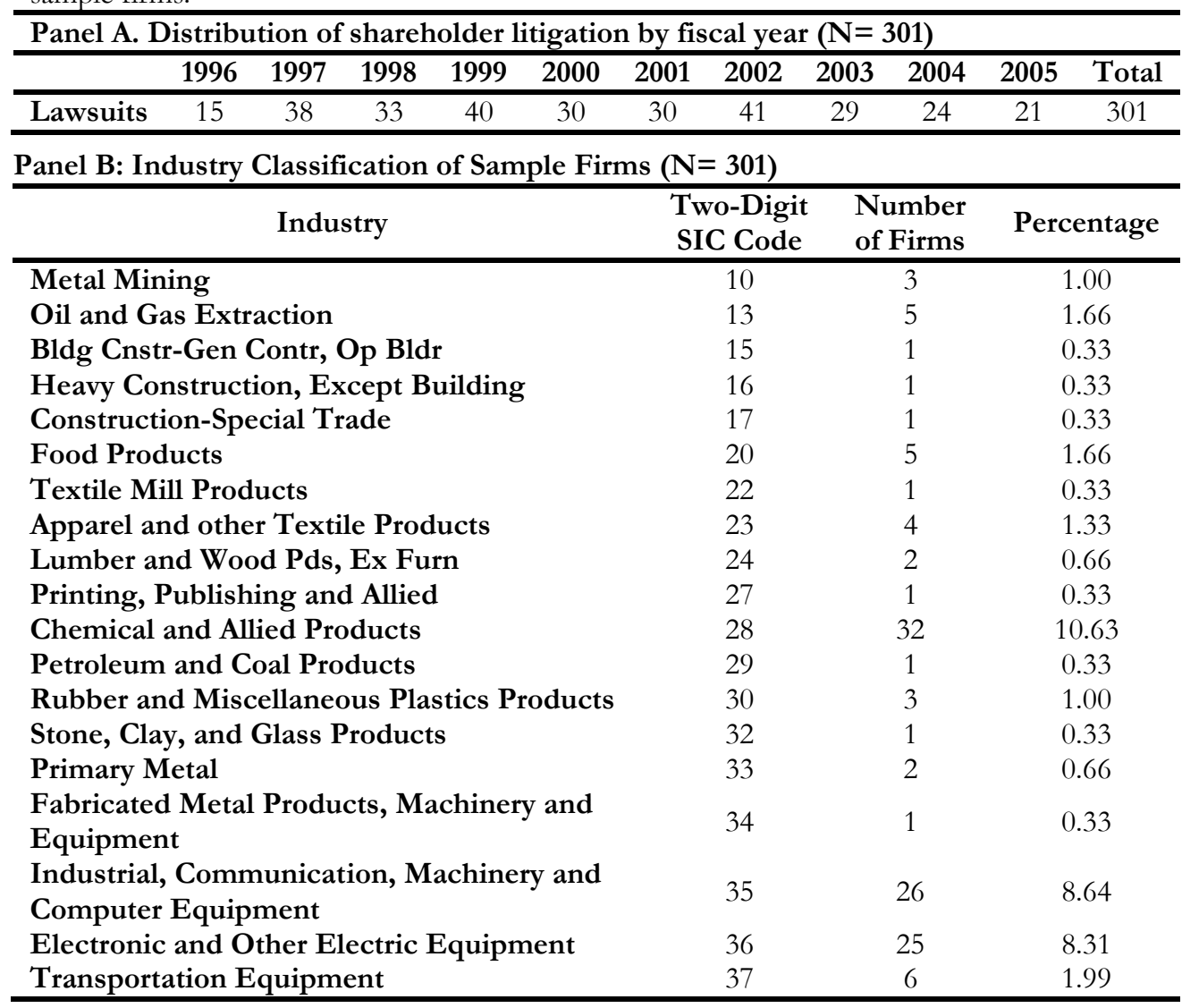


To be continue from Panel B Table 2.

\begin{tabular}{lccc}
\hline \multicolumn{1}{c}{ Industry } & $\begin{array}{c}\text { Two-Digit } \\
\text { SIC Code }\end{array}$ & $\begin{array}{c}\text { Number } \\
\text { of Firms }\end{array}$ & Percentage \\
\hline Instruments and Related Products & 38 & 18 & 5.98 \\
Miscellaneous Manufacturing & 39 & 1 & 0.33 \\
Railroad Transportation & 40 & 2 & 0.66 \\
Trucking Freight and Warehousing & 42 & 1 & 0.33 \\
Water Transportation & 44 & 1 & 0.33 \\
Transportation by Air & 45 & 1 & 0.33 \\
Transportation Services & 47 & 1 & 0.33 \\
Communications & 48 & 11 & 3.65 \\
Electric, Gas and Sanitary Services & 49 & 22 & 7.31 \\
Wholesale - Durable Goods & 50 & 3 & 1.00 \\
Wholesale - Nondurable Goods & 51 & 6 & 1.99 \\
General Merchandise Stores & 53 & 3 & 1.00 \\
Food Stores & 54 & 4 & 1.33 \\
Apparel and Accessory Stores & 56 & 2 & 0.66 \\
Furniture and Home Furnishings Stores & 57 & 3 & 1.00 \\
Eating and Drinking Places & 58 & 2 & 0.66 \\
Miscellaneous Retail & 59 & 10 & 3.32 \\
Depository Institutions & 60 & 8 & 2.66 \\
Nondepository Credit Institution & 61 & 6 & 1.99 \\
Security and Commodity Brokers & 62 & 1 & 0.33 \\
Insurance Carriers & 63 & 12 & 3.99 \\
Insurance Agents, Brokers and Service & 64 & 4 & 1.33 \\
Holding, Other Invest Offices & 67 & 2 & 0.66 \\
Hotels, Other Lodging Places & 70 & 1 & 0.33 \\
Personal Services & 72 & 2 & 0.66 \\
Business Services & 73 & 35 & 11.63 \\
Motion Pictures & 78 & 1 & 0.33 \\
Amusement and Recreation Services & 79 & 3 & 1.00 \\
Health Services & 80 & 8 & 2.66 \\
Educational Services & 87 & 2 & 0.66 \\
Engr, Acc, Resh, Mgmt, Related Services & 99 & 2 & 0.66 \\
Nonclassifiable Establishment & & 2 & 0.66 \\
\hline & $\mathbf{3 0 1}$ & $\mathbf{1 0 0}$ \\
\hline & & 2 & \\
\hline
\end{tabular}

Table 3 presents the results of the regression of Penalty Variables on Audlitig and the other model variables (Lev, LnAssets, BM, and Irregularity). In Model 1, we document a negative and statistically significant relation between 3-day CAR and Audlitig. We find that the coefficient on Audlitig is negative and statistically significant at the $5 \%$ level (coefficient: $-0.0771 ; \mathrm{p}<0.05$ ), which supports our hypothesis $\mathrm{H}_{1}$ that the market reacts negatively when the auditor is joined to the lawsuit. The coefficient on Irregularity is also negative but statistically significant at the 10\% level (coefficient: 0.0406; $\mathrm{p}<0.10$ ) in Model 1, which indicates that investors react more negatively to a securities lawsuit announcement when the lawsuit is based on an accounting irregularity.

The coefficient on Audlitig (coefficient: 5.7971; $\mathrm{p}<0.01$ ) is positive and significant at the $1 \%$ level in the settlement size regression (Model 2), implying that the settlement size is greater when the auditor is joined to the lawsuit, which supports hypothesis $\mathrm{H}_{2}$. We also find that the coefficient on Irregularity (coefficient: 5.1141; $\mathrm{p}<0.01)$ is positive and statistically significant at the $1 \%$ level, suggesting that securities 
lawsuits that are triggered by accounting irregularities are associated with larger settlements.

\section{Table 3}

\section{Regressions of 3-Day CAR, Settlement Size, and Probability of Settlement}

Table 3 presents the regressions of the three-day cumulative abnormal returns (3-day CAR) in Column $1, \log$ of the dollar settlement amount (settlement size) in Column 2, and probability of settlement (settlement) in Column 3. Lev is the ratio of total liabilities to total assets. LnAssets is the $\log$ of total assets. BM is the ratio of book to market value of equity. 3-Day CAR is the three-day cumulative abnormal returns around the announcement of litigation against the client firm. Settlement Size is the log of the dollar settlement amount. Irregularity is a binary variable equal to 1 , if the accounting misstatement is due to an irregularity, 0 , otherwise. Audlitig is equal to 1 , if the audit firm is sued, 0 , otherwise. Settlement is a binary variable equal to 1 , if the client firm settles the lawsuit, 0 , otherwise. Significance Notation: $*_{\mathrm{p}}<0.1 ; * *_{\mathrm{p}}<0.05 ; * * * \mathrm{p}<0.01$.

\begin{tabular}{lccc}
\hline \multirow{2}{*}{ Variable } & \multicolumn{3}{c}{ Models } \\
\cline { 2 - 4 } & $\begin{array}{c}\text { 3-day CAR } \\
\text { Coefficient } \\
\text { (p-value) }\end{array}$ & $\begin{array}{c}\text { Settlement Size } \\
\text { Coefficient } \\
\text { (p-value) }\end{array}$ & $\begin{array}{c}\text { Settlement } \\
\text { Coefficient } \\
\text { (p-value) }\end{array}$ \\
\hline Intercept & -0.0443 & 2.0175 & -0.6502 \\
Lev & $(0.2108)$ & $(0.2603)$ & $(0.1950)$ \\
LnAssets & $0.0930^{* *}$ & -1.5201 & -0.3849 \\
& $(0.022)$ & $(0.4545)$ & $(0.4952)$ \\
BM & -0.0042 & $0.6350^{* *}$ & 0.0614 \\
& $(0.4155)$ & $(0.0154)$ & $(0.4031)$ \\
Irregularity & -0.0275 & 2.2886 & 0.4273 \\
& $(0.6699)$ & $(0.4849)$ & $(0.6609)$ \\
Audlitig & $-0.0406^{*}$ & $5.1141^{* * *}$ & $1.5729^{* * *}$ \\
Observations & $(0.0691)$ & $(0.0000)$ & $(0.0000)$ \\
R-squared & $-0.0771^{* *}$ & $5.7971 * * *$ & $1.6677 * *$ \\
Adjusted R-squared & $(0.0145)$ & $(0.0003)$ & $(0.0103)$ \\
Residual Std. Error & 301 & 301 & 301 \\
F Statistic & 0.0607 & 0.1839 & \\
AIC & 0.0446 & 0.1704 & \\
Fisher Scoring Iterations & 0.1514 & 7.7130 & \\
\hline
\end{tabular}

Note: ${ }^{*} \mathrm{p}<0.1 ; * * \mathrm{p}<0.05 ;{ }^{* * *} \mathrm{p}<0.01$

In Model 3, the coefficient on Audlitig is positive and statistically significant at the $5 \%$ level (coefficient: 1.6677 ; $<<0.05$ ), thus supporting hypothesis $\mathrm{H}_{3}$ that the likelihood of settlement of a securities lawsuit is higher when the auditor is joined to the lawsuit. The coefficient of Irregularity is also positive but statistically significant at the $1 \%$ level (coefficient: $1.5729 ; \mathrm{p}<0.01$ ). We test for multicollinearity to confirm the validation of the models we employ in the study. The highest value of the squares of the variance inflation factors in Model 1 is 1.8518 , for Model 2 is 1.8144 , and for Model 3 is 1.7696; implying that multicollinearity is not a problem

\section{DISCUSSION AND CONCLUSION}

We examine the relation between auditor litigation and the market and legal penalties imposed on audit clients. Auditors have a fiduciary duty towards a client firm's shareholders and are deemed to be gatekeepers of capital markets (Park, 2017). 
Accordingly, auditors are expected to protect the interest of investors by providing a high-quality audit (Defond \& Zhang, 2014). Our study presents a comprehensive analysis of the merit of auditor litigation given that securities lawsuit against the auditor could signal audit failure and the auditor's culpability. Consistent with extant literature, we expect that an audit failure will result in the downward adjustment of the value of a client firm's stock price because of higher financial reporting risk (Chaney \& Philipich, 2002; Koku, 2006). We also expect that auditor litigation will increase the probability of settlement of the securities lawsuit by the client firm as well as the size of the settlement. Consistent with our hypothesis $\left(\mathrm{H}_{1}\right)$, we document a more negative investor reaction around the announcement of securities litigation against the client firm when the auditor is also sued. Consistent with our hypotheses $\mathrm{H}_{2}$ and $\mathrm{H}_{3}$, we report a higher probability of settlement of a securities lawsuit by a client firm and a larger settlement size when the auditor is also sued. Our finding that auditor litigation is associated with larger settlement sizes for sued client firms is consistent with prior studies such as Talley (2006), Donelson and Prentice (2012), Donelson (2013), which note that auditor litigation is associated with substantial settlements. Our finding that the market reacts more negatively to securities lawsuits that name the auditor as co-defendant suggests that investors perceive the joining of the external auditor to the lawsuit as a signal of audit failure and higher financial reporting risk. The present study provides evidence suggesting that in the post-PSLRA period, securities lawsuit filings against client firms in which the auditor is also sued appear to have merit. Accordingly, our study contributes to the debate on the merits of auditor litigation after the PSLRA and the findings should be of interest to regulators and market participants given the adverse impact of securities lawsuits on shareholder wealth and the substantial reputational consequences of such lawsuits on audit firms and client firms.

\section{REFERENCES}

Brasel, K., Doxey, M. M., Grenier, J. H., \& Reffett, A. (2016). Risk disclosure preceding negative outcomes: The effect of reporting critical audit matters on judgements of auditor liability. Current Issues in Auditing, 10(2), 1-10.

Brown, S., \& Warner, J. (1985). Using daily stock returns: The case of event studies. Journal of Financial Economics, 14, 3-31.

Chaney, P. K., \& Philipich, K. (2002). Shredded reputation: The cost of audit failure. Journal of Accounting Research, 40(4), 1221-1245.

Cheng, C. S. A., Huang, H. H., Li, Y., \& Lobo, G. (2010). Institutional monitoring through shareholder litigation. Journal of Financial Economics, 95(3), 356-383.

Coffee, J. C. (2006). Reforming the securities class action: An essay on deterrence and its implementation. Columbia Law Review, 106(7), 1534-1586.

Collins, D. W., Gong, G., \& Li, H. (2009). Corporate governance and backdating of executive stock options. Contemporary Accounting Research, 26(2), 403-445.

Crutchley, C. E., Minnick, K., \& Schorno, P. J. (2015). When governance fails: Naming directors in class action lawsuits. Journal of Corporate Finance, 35, 81-96.

Dee, C. C., Lulseged, A., \& Zhang, T. (2011). Client stock market reaction to PCAOB sanctions against a big 4 auditor. Contemporary Accounting Research, 28(1), 263-291.

Defond, M. L., \& Jiambalvo, J. (1994). Debt covenant violation and manipulation of accruals. Journal of Accounting \& Economics, 17(1-2), 145-176.

Defond, M., \& Zhang, J. (2014). A review of archival auditing research. Journal of Accounting \& Economics, 58(2-3), 275-326. 
Donelson, D. C. (2013). The potential for catastrophic auditor litigation. American Law \& Economics Review, 15(1), 333-380.

Donelson, D. C., \& Prentice, R. A. (2012). Scienter pleading and rule 10b-5: Empirical analysis and behavioral implications. Case Western Reserve Law Review, 63(2), 441509.

Fich, E. M., \& Shivdasani, A. (2007). Financial fraud, director reputation, and shareholder wealth. Journal of Financial Economics, 86(2), 306-336.

Franz, D. R., Crawford, D., \& Johnson, E. N. (1998). The impact of litigation against an audit firm on the market value of nonlitigating clients. Journal of Accounting, Auditing, \& Finance, 13(2), 117-134.

Fuerman, R. D. (2006). Comparing the auditor quality of Arthur Andersen to that of the big 4. Accounting \& the Public Interest, 6(1), 135-161.

Fuerman, R. D. (2012). Auditor and the post-2002 litigation environment. Research in Accounting Regulation, 24(1), 40-44.

Hossain, M., Mitra, S., Rezaee, Z., \& Sarath, B. (2011). Corporate governance and earnings management in the pre-and post-Sarbanes-Oxley act regimes: Evidence from implicated option backdating firms. Journal of Accounting, Auditing \& Finance, 26(2), 279-315.

Jensen, M. C. (2005). Agency costs of overvalued equity. Financial Management, 34(1), 519.

Jia, Y. (2014). Meeting or beating earnings benchmarks: The role of CEO integrity. Journal of Business Finance \&o Accounting, 40(3), 373-398.

Kachelmeier, S. J., Schmidt, J. J., \& Valentine, K. (2014). The effect of disclosing critical audit matters in the auditor's report on perceived auditor responsibility for misstatements. Working paper, Austin: The University of Texas.

Karpoff, J. M., Lee, S. D., \& Martin, G. S. (2008). The cost to firms of cooking the books. Journal of Financial \& Quantitative Analysis, 43(3), 581-612.

Koku, P. S. (2006). An analysis and the effects of class-action lawsuits. Journal of Business Research, 59(4), 508-515.

Krishnamurthy, S., Zhou, J., \& Zhou, N. (2006). Auditor reputation, auditor independence, and the stock-market impact of Andersen's indictment on its client firms. Contemporary Accounting Research, 23(2), 465-490.

Lee, H., \& Mande, V. (2003). The effect of the private securities litigation reform act of 1995 on accounting discretion of client managers of big 6 and non-big 6 auditors. Auditing: A Journal of Practice \& Theory, 22(1), 93-108.

Lys, T., \& Watts, R. L. (1994). Lawsuits against auditors. Journal of Accounting Research, 320, 65-93.

McTier, B. C., \& Wald, J. K. (2011). The causes and consequences of securities class action litigation. Journal of Corporate Finance, 17(3), 649-665.

Palmrose, Z. (1988). An analysis of auditor litigation and audit service quality. The Accounting Review, 63(1), 55-73.

Park, J. J. (2017). Auditor settlements of securities class actions. Journal of Empirical Legal Studies, 14(1), 169-198.

Talley, E. L. (2006). Cataclysmic liability risk among big four auditors. Columbia Law Review, 106(7), 1641-1697. 